\title{
Temporary migration, chronic effects: the health of international migrant workers in Canada
}

\author{
Kerry Preibisch PhD, Jenna Hennebry PhD
}

See related practice article by Pysklywec and colleagues on page 1039 and at www.cmaj.ca/cgi/doi/10.1503/cmaj.091404.

$\mathrm{I}$ n 2008, Canada admitted 192519 international migrant workers on temporary work 1 permits - a historical high. ${ }^{1}$ This number reflects a trend in labour migration: since 1980, the annual number of people admitted to work under temporary visas has almost always outpaced that of permanent immigrants entering the labour force annually. ${ }^{2}$ Rising numbers of migrant workers on temporary visas pose important questions for health care practitioners and researchers. ${ }^{3}$ Do migrant workers face greater risks of workrelated illnesses and injuries than Canadian citizens and landed immigrants? Are migrant workers able and likely to seek medical care? In what ways will the increasing flow of migrant workers worldwide affect public health systems, such as heightening risks of transmission of infectious diseases? In this article, we document recent trends in labour migration and begin to address these questions. We focus on migrant workers entering low-paid, low-status occupations, who account for most of Canada's foreign workforce.

\section{The growing number of international migrant workers}

Canada welcomes more net immigrants per capita than any other country. ${ }^{4}$ Although Canada's immigration policy includes humanitarian and social concerns, attracting skilled workers for economic purposes has been paramount. In 2008, economic immigrants accounted for $60.3 \%$ of those admitted as permanent residents. ${ }^{1}$ Accordingly, permanent migration flows of skilled workers have tended to dominate policy and research agendas on immigration, whereas much less is known about migrant workers on temporary visas who are invited to work but not to stay.

The number of workers entering Canada on temporary visas has increased dramatically in recent years. Some $60 \%$ of migrant workers are filling occupations designated as low skilled, primarily as farm workers and live-in caregivers (Table 1). ${ }^{5,6}$ In 2002, the federal government began implementing measures designed to liberalize flows of migrant workers, including launching an initiative that allows employers in any economic sector to hire workers from abroad to fill low-skilled occupations. Although the economic downturn has brought these strategies under review, provincial and federal governments remain committed to hiring migrant workers for certain jobs. $^{7}$

The growing recruitment of migrant workers is occurring across the industrialized West. ${ }^{8}$ Labour migration takes many forms, such as the free movement of European Union citizens from poorer member states to richer ones, and the largely unauthorized (but tacitly accepted) movement of Mexicans to the United States. Canada is unique internationally, because most of its migrant workers enter under legal work permits such as temporary employment authorizations.

\section{Migration and public health}

Increased labour migration poses challenges with respect to public health management. ${ }^{3,9}$ One concern identified by affluent countries receiving migrant workers is that the sending countries tend to have higher rates of disease and weaker and less accessible health care systems, which increases the risk of disease importation. ${ }^{10}$ Whereas the United States and France are Canada's leading source countries for highly skilled migrant workers, Mexico and the Philippines - middle-

\section{- KEY POINTS}

- Increasing numbers of international migrant workers, particularly those filling low-skill occupations in agriculture and private households, present new health challenges.

- Migrant workers tend to arrive healthy but work in jobs with existing health and safety concerns.

- Other health risks include those associated with substandard working or living conditions.

- Reasons why migrant workers may not seek health care include economic and language barriers, work schedules and a fear that use of health services might threaten their employment or immigration status. 
income countries with arguably less robust health care systems - supply most of Canada's lowskilled migrant workers (Box $1^{11}$ ).

For example, the rapid spread of pandemic (H1N1) influenza in Mexico in April 2009 and its outbreak worldwide led to fears among Canadians of potential transmission from the 18000 migrant farm workers who travel from Mexico to Canada annually. ${ }^{12,13}$ Although the World Health Organization recognized that containment through restrictions on international travel was not feasible, Mexican officials immediately implemented predeparture screening of farm workers in anticipation of negative public opinion that could threaten flows of migrant workers. ${ }^{14,15}$ Meanwhile, the Public Health Agency of Canada issued bulletins outlining the process of screening migrant farm workers and provided information to employers regarding how to identify and respond to suspected cases of pandemic (H1N1) influenza. ${ }^{16}$

Initial public reaction to "swine flu" that focused on the risk of migrant workers importing the disease reflects how migration and health issues are often framed. First, migrant workers - often people belonging to racially defined groups — are seen as potential vectors of disease. ${ }^{17,18}$ Scientific evidence shows, however, that migrant workers often are healthier upon entry than their counterparts in receiving countries or their nonmigrating peers at home because of medical prescreening, selection bias and healthy behaviours, referred to as the "healthy migrant effect."19 Second, although labour migration does play a role in disease transmission, other factors such as increased trade and tourism

Table 1: Number of positions approved for international migrant workers on temporary work permits by skill level from 2006 to 2009*

\begin{tabular}{|c|c|c|c|c|}
\hline Skill level of position & 2006 & 2007 & 2008 & 2009 \\
\hline \multicolumn{5}{|l|}{ Low skill } \\
\hline $\begin{array}{l}\text { Pilot Project for Occupations Requiring } \\
\text { Lower Levels of Formal Training } \\
\text { (National Occupational Classification } \\
\text { codes C and D) } \dagger\end{array}$ & 12304 & 32277 & 66460 & 30488 \\
\hline Live-in Caregiver Program & 25632 & 33532 & 34732 & 20861 \\
\hline Seasonal Agricultural Worker Program & 24050 & 26622 & 28231 & 27654 \\
\hline Total, low skill & 61986 & 92431 & 129423 & 79003 \\
\hline High skill (managerial/professional/skilled)‡ & 52893 & 63057 & 74545 & 52371 \\
\hline Total & 114879 & 155488 & 203968 & 131374 \\
\hline
\end{tabular}

*Figures reflect positions approved by Human Resources and Skills Development Canada through a labour market opinion as opposed to the number of actual positions filled. In addition, not all people with a temporary work visa require a labour market opinion to receive a work permit. tNational Occupation Classification (NOC) codes identify skill levels that correspond to the type and amount of training or education typically required to work in an occupation $(0=$ management occupations, $A=$ professionals, $B=$ skilled and technical, $C=$ intermediate and clerical, $\mathrm{D}=$ elemental and labourers). For this table, codes $0, \mathrm{~A}$ and $\mathrm{B}$ refer to high-skill positions, and codes $C$ and $D$ refer to low-skill positions.

FThis category includes occupations designated as high skilled (NOC codes $0, A$ and B) as well as occupations outside of the programs listed in the table.

Source: Human Resources and Skills Development Canada.
Box 1: Facts and figures about temporary migrant workers in Canada in 2008

- Number of migrant workers admitted to Canada: 192519

- Top sending countries: United States (31 399), Mexico (20 900) and the Philippines (19 253)

- Ratio of men to women admitted: 2:1

- Total number of migrant workers in Canada as of Dec. 1, 2008: 251235

- Three top employers by province: Ontario (91 276), British Columbia (58 307) and Alberta (57 707)

Source: Human Resources and Skills Development Canada.

are more salient.$^{20}$ Finally, a focus on disease importation often results in health risks to migrant workers within receiving countries being underexamined, despite their potential to adversely affect migrant workers' health or to lead to serious public health concerns. ${ }^{21,22}$

The health risks to migrant agricultural workers in particular have been underexamined. In North America, employers often provide overcrowded housing for farm workers, which increases the risk of transmission of infectious diseases such as tuberculosis. ${ }^{23,24}$ Poor sanitation and inadequate means to refrigerate and heat food, along with insufficient toilet and handwashing facilities at worksites, may also heighten the risk of farm workers developing and spreading enteric, foodand waterborne diseases. ${ }^{25,26}$ The implications for Canada's food system, given the increasing numbers of migrant workers employed in agriculture, meat processing and food services, is a major public health concern. ${ }^{23}$ In 2007 , for example, more than 30000 confirmed positions for international migrant workers were in the agrifood sector, including jobs such as hand-harvesting, meat cutting and butchering, and the processing, preparation and serving of food and beverages. ${ }^{5}$

\section{Health risks to migrant workers}

In most affluent countries, reliable statistics are not available to determine whether international migrant workers are in a higher risk category than local workers. ${ }^{27}$ Research in Europe indicates, however, that migrant workers may be at increased risk of workplace injuries or accidents because they are concentrated in occupations typically rejected by local residents because of existing health and safety concerns. ${ }^{27-29}$ Jobs in agriculture and live-in caregiving constitute two such occupations in Canada and worldwide. . $^{30,31}$ Studies have shown that migrant farm workers face elevated workplace health and safety risks, 
with common health problems related to chemical exposure, single-event injury and musculoskeletal injuries. ${ }^{26,32}$ A study of farm workers in the United Kingdom, most of whom were migrant workers, showed that self-perceived health status was significantly lower than population norms. ${ }^{33}$ For migrant caregivers, working conditions have also been linked to a range of physical and mental health problems. ${ }^{34}$

Migrant workers may also face additional risks in their status as new workers. ${ }^{29}$ They may receive less training than local workers or confront language barriers that render training less effective. ${ }^{25,26,29}$ Given the considerable wage differentials between countries sending and those receiving migrant workers, migrant workers may also act to protect their jobs in ways that could increase workplace health and safety risks. For example, research has shown that migrant workers are less likely than local workers to request safety equipment or report potential hazards or accidents, and more likely to accept unsafe work or work when ill or injured, because of a fear of loss of employment or legal status. ${ }^{25,26,35}$ Migrant workers often work longer hours than local workers because of the precarious nature of their jobs, a desire to maximize earnings and limited social commitments outside work, since many are not allowed or able to migrate with their families. ${ }^{25,27,29,36}$ Research in the United Kingdom has shown that, in addition to working longer hours, migrant workers are more likely to be employed in working patterns or conditions that can contribute to health and safety risks, such as night shifts. ${ }^{29}$ In Canada, migrant workers filling low-skill jobs are particularly vulnerable because their work visas are tied to a single, named employer, and changing employers is difficult (Box 2).22,23,26

Risks associated with living conditions and lifestyles are another concern. In Canada, migrant farm workers and caregivers often live on their employers' property. For farm workers, weak regulation and poor enforcement has meant that some housing is dilapidated, unsanitary, overcrowded and poorly ventilated. ${ }^{25,26} \mathrm{In}$ surveys of migrant farm workers, $37 \%$ in British Columbia and 27\% in Ontario perceived their housing to be damaging to their health. ${ }^{25,26}$ For migrant caregivers, the live-in arrangement has left some women vulnerable to sexual harassment, while fears of interference or threats to their employment and immigration status have impeded the reporting of complaints. ${ }^{30,36,37}$ Marginalization, discrimination and isolation augment the stress and loneliness experienced by migrant workers coping with family separation, social and geographic isolation, and little or no opportunities for recreational activities. ${ }^{38}$
Research in Korea has shown that isolation and the anonymity afforded while being in a foreign country lead some migrant workers to take risks that expose them to sexually transmitted infections ${ }^{39}$ Lack of knowledge about prevention programs further increases the likelihood of transmission between migrant workers and people in the communities in which they reside. ${ }^{38,39}$ In the United States, migrant farm workers have been found to be at higher risk of depression, anxiety, suicide and substance abuse than the general population. ${ }^{32}$ Research has corroborated similarly heightened risks of sexually transmitted infection and mental illness among migrant farm workers in Canada. ${ }^{40}$

As stated earlier, Canada is unique internationally because most of its migrant workers are employed under legal employment authorizations. Migrant workers without legal documents face different challenges that affect their health status. They tend to undergo long, dangerous journeys, spend periods living precariously in transit to their destinations and are often confined upon arrival in detention camps. The health-related issues that result have been less acute in Canada than in other affluent Western countries that receive high numbers of unauthorized migrant workers, such as the United States, France and Spain.

Canada's increasingly restrictive immigration and refugee policies, however, are cause for some concern. For one, migrant workers must resort to ever more dangerous routes to enter the country, as highlighted by the 76 Tamil would-be migrant workers who arrived off Vancouver Island in October 2009..$^{41,42}$ Second, few migrant workers entering on a temporary work visa (which lasts 24 months at most for lower-skilled workers) have legal avenues to stay in the country after the

Box 2: Factors that heighten vulnerability of migrant workers in low-skill occupations 17,22,23,25,26,29 $^{2}$

- Frequent and temporary migration

- Migration status dependent on employment status, work permit tied to employer

- Concentration in occupations with existing health and safety concerns

- Insufficient health screening in countries of origin and destination

- Barriers to health care, health insurance

- Lack of independent monitoring of health and safety violations

- Insufficient safety equipment and training

- Lack of information, representation and support

- Poor and underregulated housing

- Social exclusion, isolation

- Linguistic and cultural differences, high rates of illiteracy

- Lack of mechanism to assist workers in changing employers

- No direct path to permanent residency

- Debts to third-party recruiters and intermediaries 
visa expires..$^{43}$ In addition, Canada's increased reliance on temporary labour migration has contributed to a growing undocumented workforce. ${ }^{44}$ Employer-specific work visas and the restrictions migrant workers face when seeking to change employers have led some to desert their worksites when faced with mistreatment or less-thanpromised wages or hours. Moreover, abuses arising from the inadequate monitoring of recruitment and employment of migrant workers have driven others into the underground economy.

\section{Access to medical care}

Research on migrant workers' access to medical care is limited. Although studies exploring their use of health care services are available, the diversity in the definition of migrant status and control of variables complicates cross-national and international comparative analyses. ${ }^{9,45}$

Despite shortcomings in the data, research in Europe indicates systematic differences in utilization patterns among migrant workers that are likely due to problems of access to health care. ${ }^{9}$ Other studies have identified a range of barriers to health care for migrant workers in Europe, Oceania and North America, even in countries where access to health care is guaranteed. ${ }^{46}$ Economic barriers are substantial. Uncertainty regarding whether migrants will have to pay for treatment, as well as the cost of the treatment, contribute to delays in access. ${ }^{17,22,46}$ In Canada, many authorized migrant workers are not eligible for publicly funded health care until three months following arrival, and undocumented migrant workers may have no access at all. ${ }^{25,26}$ Although private insurance may fill this gap, service provision that obliges users to pay up front can lead some workers to forgo medical care. ${ }^{23,25}$

Linguistic and cultural differences have been identified as barriers to migrant workers' willingness to seek health care and the quality of treatment

\section{Box 3: Research gaps}

- Knowledge of health issues associated with labour migration to Canada and internationally is inadequate.

- Clinical studies involving migrant workers in Canada are lacking, as is a greater understanding of the social context of health issues of migrant workers.

- Challenges to research involving migrant workers - a less visible population within Canadian society - are further hindered by restrictive access to government data.

- Migrant workers are a heterogeneous population. Researchers must take into account diverse premigration histories, the circumstances under which migration occurs, and distinct realities of employment and settlement.

- Cross-national and international comparative analyses are hampered by the lack of a single accepted definition of migrant status and methods of identification, as well as a lack of reliable and valid health care data. they receive. ${ }^{9,47}$ Lack of linguistic and cultural sensitivity on the part of health care providers and employers can lead to perceptions of substandard care among migrant workers and become a barrier to access. ${ }^{21}$ In a study of the use of health services among international migrant workers in Portugal, $18 \%$ of respondents identified providers' attitudes as a barrier to access. ${ }^{46}$ Medical professionals are generally not trained and lack the resources to recognize the social context of migrant workers' health, which results in a failure to acknowledge, address and treat their health concerns adequately. ${ }^{21}$

Moreover, migrant workers in low-skill occupations often work long hours, which leaves them little time to seek health care or available time that does not coincide with clinic hours. ${ }^{35}$ Lack of information, and physical and social isolation act as additional barriers to medical treatment, and in particular live-in caregivers may face workrelated isolation. ${ }^{34}$ In Canada, migrant workers in rural or remote settings may find that walk-in clinics — often their first contact with the health care system - do not recognize private insurance or lack the diagnostic equipment or specialization to detect workplace-related health concerns..$^{25}$

Migrant workers may also fail to use health services out of fear that it will interfere or threaten their employment and immigration status. ${ }^{35,46}$ In Canada, stipulations that oblige migrant live-in caregivers and farm workers to reside on their employers' property may contribute to delays in seeking medical care if migrant workers are reticent to inform employers of their health concerns. ${ }^{26,30}$ Migrant farm workers, for example, have been repatriated for becoming ill, injured or pregnant while working in Canada; this has led women to conceal or terminate pregnancies and to forgo antenatal care..$^{48}$ Live-in caregivers may also fear that raising concerns or seeking available services could risk deportation or jeopardize their application for permanent residency, for which they are eligible after 24 months of continuous employment. ${ }^{22}$

Limited literacy, language barriers and fear are also major barriers to reporting accidents or filing for workers' compensation. ${ }^{23}$ At times, injured migrant workers have found themselves ineligible for compensation because they had been told to perform tasks outside their job description or to work for someone other than their employer. ${ }^{40,49}$ Research has documented instances of employers discouraging or impeding migrant workers from filing claims and of migrant workers having difficulties claiming for compensation after being deported. ${ }^{40,50}$ Finally, health care practitioners often lack sufficient knowledge of migrant workers' eligibility for workers' compensation or the procedures involved. ${ }^{40}$ 


\section{Conclusion}

Popular portrayals of migrant workers as "vectors of disease" who ought to be stopped at the border are misleading. International migrant workers tend to arrive healthy, and all undergo medical screening as part of their visa application. If their health status deteriorates while in Canada, it is more likely due to their new working and living conditions than a pre-existing condition. Furthermore, migrant workers' vulnerability may lead to delays or failure to report health concerns or receive treatment, a situation that can lead to more serious public health problems, both in Canada and in the countries of origin. Although labour migration through the Foreign Worker Program is intended to be temporary, the consequences are likely to be increasingly permanent for migrant workers and Canadians alike.

International migrant workers comprise an extremely diverse group and undoubtedly, specific categories of temporary workers will be at greater risk than others in terms of health outcomes. In this article, we have focused on the limited literature on migrant workers in low-skill occupations. More detailed and reliable information on health risks, outcomes and disease transmissibility among migrant workers is needed to provide adequate health care to this vulnerable group, to track and monitor occupational and communicable diseases, and to develop effective interventions (Box 3).

Some immediate measures to better address health issues of migrant workers include granting them immediate access to provincial health care upon arrival; exercising more stringent enforcement of workplace health and safety; implementing medical screening at the end of the work term that guarantees workers receive adequate care before returning home; and improving the delivery of health and safety information to migrant workers and health care practitioners.

\section{References}

1. Facts and figures 2009 - immigration overview: permanent and temporary residents. Ottawa (ON): Statistics Canada; 2009. Available: www.cic.gc.ca/English/resources/statistics/menu-fact .asp (accessed 2011 Apr. 1).

2. Sharma N. Home economics: nationalism and the making of migrant workers in Canada. Toronto (ON): University of Toronto Press; 2006

3. Gushulak BD, MacPherson DW. Population mobility and infectious diseases: the diminishing impact of classical infectious diseases and new approaches for the 21st century. Clin Infect Dis 2000;31:776-80.

4. Dolin B, Young M. Canada's immigration program. Ottawa (ON): Library of Parliament; 2004.

5. Human Resources and Social Development Canada. The Temporary Foreign Worker Program: recent figures and policy development. National Metropolis Conference; 2008 Apr. 3-6; Halifax (NS).

6. Temporary Foreign Worker Program: labour market opinion (LMO) statistics — annual statistics 2006-2009. Ottawa (ON): Human Resources and Skills Development Canada; 2010. Avail- able: www.hrsdc.gc.ca/eng/workplaceskills/foreign_workers /stats/annual/annual_stats_list.shtml (accessed 2010 Apr. 13).

7. Galloway G. Immigration levels could take hit, Kenney says. Globe and Mail [Toronto] 2009 Feb. 11.

8. Castles S. Guestworkers in Europe: A resurrection? Int Migr Rev 2006; $40: 741-66$

9. Norredam M, Nielsen SS, Krasnik A. Migrants' utilization of somatic health care services in Europe - a systematic review. Eur J Public Health 2009; doi:10.1093/eurpub/ckp195. Available: http://eurpub.oxfordjournals.org/cgi/content/abstract /ckp195v1 (accessed 2009 Dec. 29)

10. Commission on Social Determinants of Health. Closing the gap in a generation: health equity through action on the social determinants of health. Geneva (Switzerland): World Health Organization; 2008

11. Temporary Foreign Worker Program: labour market opinion (LMO) statistics — annual statistics 2005-2008. Ottawa (ON): Human Resources and Skills Development Canada; 2009.

12. Peritz I. Flu outbreak leaves Mexican workers in limbo. Globe and Mail [Toronto]. 2009 Apr. 27.

13. Canada will monitor, not bar Mexican farm workers. Ottawa $(\mathrm{ON})$ : CBC News; 2009. Available: www.cbc.ca/news/canada /toronto/story/2009/04/27/montreal-migrantworkers-swine-0427 .html?ref=rss (accessed 2011 Mar. 23).

14. Contingencia Sanitaria no ha interrumpido programa de jornaleros agrícolas México-Canadá: STPS [article in Spanish]. Mexico City (Mexico): Presidencia de la República; 2009.

15. Swine influenza. Statement by WHO Director-General Margaret Chan. Geneva (Switzerland): World Health Organization; 2009. Available: www.who.int/mediacentre/news/statements/2009 /h1n1_20090427/en/index.html (accessed 2009 May 27).

16. Public Health Agency of Canada. H1N1 flu virus: background on government actions. Ottawa (ON): The Agency; 2009. Available: www.phac-aspc.gc.ca/media/nr-rp/2009/2009_0507b _h1n1-eng.php (accessed 2010 Mar. 1).

17. Littleton J, Park J, Thornley C, et al. Migrants and tuberculosis: analysing epidemiological data with ethnography. Aust $N \mathrm{ZJ}$ Public Health 2008;32:142-9.

18. Grove NJ, Zwi AB. Our health and theirs: forced migration, othering, and public health. Soc Sci Med 2006;62:1931-42.

19. Vissandjee B, Desmeules M, Cao Z, et al. Integrating ethnicity and migration as determinants of Canadian women's health. BMC Womens Health 2004;4(Suppl 1):S32.

20. Carballo M, Mourtala M. International migration and health. A paper prepared for the Policy Analysis and Research Programme of the Global Commission on International Migration. Geneva (Switzerland): Global Commission on International Migration; 2005. Available: www.gcim.org/attachements/TP13.pdf (accessed 2011 Apr. 6).

21. Holmes $\mathrm{S}$. An ethnographic study of the social health of migrant workers in the United States. PLos Med 2006;10:e448.

22. Oxman-Martinez J, Hanley J, Lach L, et al. Intersection of Canadian policy parameters affecting women with precarious immigration status: a baseline for understanding barriers to health. J Immigr Health 2005; 7:247-58.

23. Hennebry JL. International agricultural migration and public health: examining migrant farm worker health and the public health implications of agricultural temporary migration. Ottawa (ON): Public Health Agency of Canada; 2008.

24. Ciesielski S, Esposito D, Protiva J, et al. The incidence of tuberculosis among North Carolina migrant farmworkers, 1991. Am J Public Health 1994;84:1836-8.

25. Otero G, Preibisch K. Farmworker health and safety: challenges for British Columbia. Vancouver (BC): WorkSafeBC; 2010.

26. Hennebry J, Preibisch K, McLaughlin J. Health across borders health status, risks and care among transnational migrant farm workers in Ontario. 2010, Toronto (ON): CERIS - the Ontario Metropolis Centre; 2009.

27. Ambrosini M, Barone C. Employment and working conditions of migrant workers. Dublin (Ireland): European Foundation for the Improvement of Living and Working Conditions; 2006. p. 66.

28. Elkeles T, Seifert W. Immigrants and health: unemployment and health-risks of labour migrants in the Federal Republic of Germany, 1984-1992. Soc Sci Med 1996;43:1035-47.

29. McKay S, Craw M, Chopra D. Migrant workers in England and Wales: an assessment of migrant worker health and safety risks. London (UK): Health and Safety Executive; 2006.

30. Arat-Koc S. In the privacy of our own home: foreign domestic workers as solution to the crisis in the domestic sphere in Canada. Stud Polit Econ 1989;28:33-58.

31. Bolaria BS, Basran GS, Hay D. The health effects of powerlessness: the case of immigrant farm labour, in the political economy of agriculture in western Canada. Toronto (ON): Garamond Press; 1988. p. 109-24. 
32. Hansen E, Donohue M. Health issues of migrant and seasonal farmworkers. J Health Care Poor Underserved 2003;14:153-64.

33. Cross P, Edwards RT, Hounsome B, et al. Comparative assessment of migrant farm worker health in conventional and organic horticultural systems in the United Kingdom. Sci Total Environ 2008;391:55-65.

34. Holroyd EA, Molassiotis A, Taylor-Pilliae RE. Filipino domestic workers in Hong Kong: health related behaviors, health locus of control and social support. Women Health 2001;33:181-205.

35. Arcury TA, Quandt SA. Delivery of health services to to migrant and seasonal farmworkers. Annu Rev Public Health 2007;28:345-63.

36. Stasiulis DK, Bakan A. Negotiating citizenship: migrant women in Canada and the global system. Houndsmill (UK): PalgraveMacmillan; 2003.

37. Welsh S, Carr J, MacQuarrie B, et al. "I'm not thinking of it as sexual harassment": understanding harassment across race and citizenship. Gend Soc 2006;20:87-107.

38. Hovey JD, Booker V, Seligman LD. Using theatrical presentations as a means of disseminating knowledge of HIV/AIDS risk factors to migrant farmworkers: an evaluation of the effectiveness of the Infórmate program. J Immigr Minor Health 2007:9:147-56.

39. Lee J. Migrant workers and HIV vulnerability in Korea. Int Migr 2008;46:217-33.

40. McLaughlin J. Trouble in our fields: health and human rights among Mexican and Caribbean migrant farm workers in Canada. Toronto (ON): University of Toronto; 2009.

41. Armstrong J, Ibbitson J. Seeking a safe haven, finding a closed door. Globe and Mail [Toronto]. 2009 Oct. 20.

42. Beers D. Don't treat Ocean Lady passengers as criminals: watchdog group. The Tyee [Vancouver]. 2009 Oct. 19.

43. Hennebry JL, Preibisch K. A model for managed migration? Reexamining best practices in Canada's seasonal agricultural worker program. International Migration. doi: 10.1111/j.14682435.2009.00598.x.

44. Contenta S, Monsebraaten L. How we're creating an illegal workforce: controversial federal program brings in foreigners for temporary jobs, but leaves them ripe for abuse. Toronto Star. 2009 Nov. 1.

45. Nielsen S, Krasnik A, Rosano A. Registry data for cross-country comparisons of migrants' health care utilization in the EU: a survey study of availability and content. BMC Health Services Research 2009;9:210.

46. Dias S, Severo M, Barros H. Determinants of health care utilization by immigrants in Portugal. BMC Health Services Research 2008;8:207.

47. Anthony M, Williams JM, Avery AM. Health needs of migrant and seasonal farmworkers. J Community Health Nurs 2008;25:153-60.

48. Preibisch K, Encalada Grez E. The other side of "El Otro Lado": Mexican migrant women and labor flexibility in Canadian agriculture. Signs 2010;35:289-316.

49. Verduzco G, Lozano MI. Mexican workers' participation in CSAWP and development consequences in the workers' rural home communities. Ottawa (ON): North-South Institute; 2003.

50. Downes A, Odle-Worrell C. Barbados, Trinidad \& Tobago OECS workers' participation in CSAWP and development consequences in the workers' rural home communities. Ottawa (ON): North-South Institute; 2003.

Affiliations: From the Departments of Sociology and Anthropology (Preibisch), University of Guelph, Guelph, Ont.; and the Balsillie School for International Affairs and the International Migration Research Centre (Hennebry), Wilfrid Laurier University, Waterloo, Ont.

Contributors: Both authors contributed substantially to the writing and revising of the manuscript and approved the final version submitted for publication.

Funding: This work was supported by a grant from CERIS - the Ontario Metropolis Centre and by funding from the Public Health Agency of Canada in the form of honoraria and travel support. 